\title{
IFI44 wt Allele
}

National Cancer Institute

\section{Source}

National Cancer Institute. IFl44 wt Allele. NCI Thesaurus. Code C123867.

Human IFI44 wild-type allele is located in the vicinity of 1 p31.1 and is approximately $14 \mathrm{~kb}$ in length. This allele, which encodes interferon-induced protein 44, may be involved in interferon-mediated viral responses. 